\title{
Catalytic processing of distillate fractions of a resin in the presence of finely dispersed catalysts
}

\author{
Nazym Smagulova ${ }^{-}$, Zhaxyntay Kairbekov and Nurlan Ussenov \\ Al-Farabi Kazakh National University, 050040 Almaty, Kazakhstan
}

\begin{abstract}
The article describes the catalytic cracking of heavy oil residue in the presence of a finely dispersed catalyst. It was determined that in the processing of high molecular weight hydrocarbons, catalysts are effective, which are uniformly distributed in the volume of raw materials and are introduced into the technological process in the form of small particles. Coke tar mainly consists of $27.00 \mathrm{wt} . \%$ asphaltenes, $60.00 \mathrm{wt} . \%$ of polyaromatic hydrocarbons that have been studied and identified as a potential source of raw materials to produce motor fuels in the future.
\end{abstract}

\section{Introduction}

The increased demand for motor fuels requires further development of deep processing of high molecular weight petroleum feedstock, as well as solid combustible minerals (coal, shale, peat). Coal (coking) tar, consisting mainly of condensed aromatic hydrocarbons and other high-molecular compounds refers to hard-processed raw materials. In industry, the tar is subjected to dehydration and distillation into separate fractions, from which benzene, naphthalene, phenols, pyridine bases and other chemical products are obtained by the methods of alkaline and acid extraction, crystallization, hydro-treatment. At present, the increasing requirements for product quality require the improvement of technological schemes, as well as methods of processing high molecular weight raw materials.

Saryarka Spetskoks LLP uses Chinese technology to produce 30 thousand tons of resin and 300 thousand tons of special coke per year during coal processing. This resin is not currently undergoing any processing. The process of partial coking of coal is carried out at a temperature of $500-550{ }^{\circ} \mathrm{C}$. The volatiles generated in the process do not pass completely through the zone heated by the furnace to a temperature of $700-750{ }^{\circ} \mathrm{C}$, and are less susceptible to secondary high-temperature pyrolysis. Therefore, the quality of the resin released in the process matches the quality of the primary resin. Therefore, the object of the study was a coke-chemical tar obtained by semicoking coal from the Shubarkol deposit [1].

\footnotetext{
- Corresponding author: nazym2011@,inbox.ru
} 


\section{Experimental}

The process of cracking the distillate products obtained by hydrogenating the resin to $320^{\circ} \mathrm{C}$ is carried out at a much lower temperature of $400-450{ }^{\circ} \mathrm{C}$ compared to the high temperature of $550-560^{\circ} \mathrm{C}$, which is produced by industrial enterprises at a pressure of 3.0 $\mathrm{MPa}$. Dispersion of raw materials with a mass of $\mathrm{Na}_{2} \mathrm{SiO}_{3}$ catalyst is carried out in a disperser with a rotation speed of $1800 \mathrm{rpm}$. The experiments were carried out in a highpressure laboratory setup with a $0.25 \mathrm{dm}^{3}$ hollow reactor and a stirring device. A mixture of resin with a catalyst and sulfur addition, heated to $70-80{ }^{\circ} \mathrm{C}$, was loaded into a reactor, which was preliminarily purged with argon and filled with hydrogen at an initial pressure of 2-3 MPa. The heating of the reactor was switched on, and upon reaching $150{ }^{\circ} \mathrm{C}$, the stirring device. The temperature was measured with a thermocouple and automatically maintained with an accuracy of $\pm 2{ }^{\circ} \mathrm{C}$. The working pressure of hydrogen was $5.0 \mathrm{MPa}$, the temperature was $350-450^{\circ} \mathrm{C}$, and the reaction time was $15 \mathrm{~min}$. A hydrogen pressure of 5.0 $\mathrm{MPa}$ was selected as effective on the basis of experimental data [2] and the results obtained in [3].

In the course of the study, a fraction boiling at temperatures above $350{ }^{\circ} \mathrm{C}$, obtained at a vacuum distillation unit at the PetroKazakhstan Products refinery, was used as a hydrogen donor-pasteurizer.

\section{Results and discussion}

Were determined the physicochemical properties of coke tar for further production of motor fuels (Table 1).

Table 1. Physical and chemical properties of coke tar

\begin{tabular}{|c|c|}
\hline Indicator name & Indicator \\
\hline 1 & 2 \\
\hline Mass fraction of water, $\%$ & 3.420 \\
\hline Density at $20^{\circ} \mathrm{C}, \mathrm{kg} / \mathrm{m}^{3}$ & 1.085 \\
\hline Mass fraction of insoluble substances in toluene, $\%$ & 1.310 \\
\hline Mass fraction of insoluble substances in quinoline, $\%$ & 0.210 \\
\hline Ash content & 0.110 \\
\hline \multicolumn{2}{|c|}{ Fractional distillation: } \\
\hline Initial boiling point, ${ }^{\circ} \mathrm{C}$ & 130 \\
\hline Up to $180^{\circ} \mathrm{C}$ & 2.610 \\
\hline $180-230^{\circ} \mathrm{C}$ & 11.25 \\
\hline $230-280^{\circ} \mathrm{C}$ & 8.17 \\
\hline $280-330^{\circ} \mathrm{C}$ & 10.55 \\
\hline Above $330^{\circ} \mathrm{C}+$ residue & 68.12 \\
\hline \multicolumn{2}{|c|}{ Elemental composition, wt. \%: } \\
\hline ( & 91.90 \\
\hline $\mathrm{H}$ & 5.65 \\
\hline$S$ & 0.47 \\
\hline $\mathrm{N}$ & 0.78 \\
\hline $\mathrm{O}$ & 1.62 \\
\hline \multicolumn{2}{|c|}{ Analysis of pitch after resin distillation: } \\
\hline Softening temperature, ${ }^{\circ} \mathrm{C}$ & 68.10 \\
\hline Volatile matter yield, $\%$ & 83.05 \\
\hline Ash content, $\%$ & 0.215 \\
\hline
\end{tabular}




\begin{tabular}{|l|c|}
\hline \multicolumn{1}{|c|}{1} & 2 \\
\hline Mass fraction of insoluble substances in toluene, $\%$ & 11.35 \\
\hline Mass fraction of insoluble substances in quinoline, $\%$ & 0.32 \\
\hline Mass fraction of phenols, $\%$ & 18.31 \\
\hline Mass fraction of naphthalene, $\%$ & 0.44 \\
\hline Flash point, ${ }^{\circ} \mathrm{C}$ & 121.05 \\
\hline Calorific value, $\mathrm{kcal} / \mathrm{kg}$ & 8385 \\
\hline Conditional viscosity at $80^{\circ} \mathrm{C},{ }^{\circ} \mathrm{VC}$ & 1.67 \\
\hline Coke, $\%$ & $2.30-3.45$ \\
\hline Mass fraction of sulfur, $\%$ & 0.055 \\
\hline Resins, acphaltenes, $\%$ & 27.05 \\
\hline Polyaromatic hydrocarbons, $\%$ & 60.10 \\
\hline Correlation index & $108-128$ \\
\hline Boiling point, ${ }^{\circ} \mathrm{C}$ & $112-122$ \\
\hline Mass fraction of ions $\mathrm{Na}, \%$ & $0.015-0.025$ \\
\hline Mass fraction of ions $\mathrm{K}^{-} \%$ & $0.030-0.040$ \\
\hline Melting point, ${ }^{\circ} \mathrm{C}$ & 20.10 \\
\hline
\end{tabular}

The influence of the weight and temperature of the catalyst on the process was studied in order to reduce the operating pressure of the hydrotreating process and to determine the optimal conditions for the cracking of coke distillate products (Table 2).

Table 2. Results of cracking of distillate resin fractions in the presence of $\mathrm{Na}_{2} \mathrm{SiO}_{3} \cdot 10 \mathrm{H}_{2} \mathrm{O}$ catalyst

\begin{tabular}{|c|c|c|c|c|c|c|c|c|}
\hline \multirow{2}{*}{ Catalyst } & \multirow[t]{2}{*}{$\mathrm{T},{ }^{\circ} \mathrm{C}$} & \multicolumn{3}{|c|}{ The yield of liquid products, wt.\% } & \multirow{2}{*}{$\sum$ L.P. } & \multirow{2}{*}{$\begin{array}{c}\text { Gas } \\
\text { output, } \\
\text { wt.\% }\end{array}$} & \multirow{2}{*}{$\begin{array}{c}\text { Resid } \\
\text { ue, } \\
\text { wt.\% }\end{array}$} & \multirow{2}{*}{$\begin{array}{l}\text { Loss, } \\
\text { wt. } \%\end{array}$} \\
\hline & & $\begin{array}{l}\text { Up to } \\
180^{\circ} \mathrm{C}\end{array}$ & $\begin{array}{c}180- \\
250^{\circ} \mathrm{C}\end{array}$ & $250-320^{\circ} \mathrm{C}$ & & & & \\
\hline \multirow{3}{*}{$\begin{array}{l}\text { Without } \\
\text { cat. }\end{array}$} & 400 & 9.8 & 8.6 & 15.7 & 34.3 & 17.9 & 27.7 & 14.0 \\
\hline & 420 & 6.3 & 10.5 & 17.2 & 33.9 & 22,9 & 35,0 & 8.2 \\
\hline & 450 & 9.3 & 14.3 & 34.0 & 57.6 & 13.9 & 15.1 & 13.4 \\
\hline \multirow{3}{*}{$\begin{array}{l}1.0 \text { wt. } \% \\
\mathrm{Na}_{2} \mathrm{SiO}_{3} \\
10 \mathrm{H} 2 \mathrm{O}\end{array}$} & 400 & 12.6 & 17.3 & 18.6 & 48.5 & 27.7 & 18.1 & 5.8 \\
\hline & 420 & 11.3 & 18.4 & 20.8 & 50.5 & 24.5 & 17.4 & 7.6 \\
\hline & 450 & 13.7 & 24.0 & 20.7 & 58.4 & 17.3 & 10.9 & 13.4 \\
\hline \multirow{3}{*}{$\begin{array}{l}2.0 \text { wt. } \% \\
\mathrm{Na}_{2} \mathrm{SiO}_{3} \\
10 \mathrm{H}_{2} \mathrm{O}\end{array}$} & 400 & 14.6 & 25.3 & 20.6 & 60.5 & 10.7 & 19.1 & 9.7 \\
\hline & 420 & 13.3 & 26.4 & 25.8 & 65.5 & 14.5 & 10.0 & 9.8 \\
\hline & 450 & 15.7 & 34.0 & 26.7 & 68.4 & 12.3 & 8.0 & 11.3 \\
\hline \multirow{3}{*}{$\begin{array}{l}3.0 \text { wt. } \% \\
\mathrm{Na}_{2} \mathrm{SiO}_{3} \\
10 \mathrm{H}_{2} \mathrm{O}\end{array}$} & 450 & 14.6 & 28.3 & 23.6 & 66.5 & 7.7 & 16.1 & 9.7 \\
\hline & 450 & 13.7 & 34.0 & 20.7 & 68.4 & 7.3 & 11.9 & 12.4 \\
\hline & 450 & 17.3 & 30.4 & 30.8 & 78.5 & 4.5 & 9.1 & 7.9 \\
\hline
\end{tabular}


As can be seen from the table, during the process at a temperature of $450^{\circ} \mathrm{C}$ and an increase in the amount of the catalyst $\mathrm{Na}_{2} \mathrm{SiO}_{3} \cdot 10 \mathrm{H}_{2} \mathrm{O}$ from $1.0 \mathrm{wt} \%$ up to $2.0 \mathrm{wt}$. \% the yield of liquid products in comparison with those obtained without catalyst increases from 57.60 wt. $\%$ up to $60.50 \mathrm{wt} . \%$, including gasoline fraction from $9.30 \mathrm{wt} \%$ increased by 15.70 wt.\%. At the same temperature, with an increase in the amount of catalyst by $1.0 \mathrm{wt} . \%$, the yield of the liquid products from $68 \mathrm{wt}$. \% increased by $78.50 \mathrm{wt} \%$, and the gasoline fraction from $15.70 \mathrm{wt} . \%$ increased by $17.30 \mathrm{wt} . \%$. At $450{ }^{\circ} \mathrm{C}$, the yield of liquid products in the presence of $3.0 \mathrm{wt}$. \% the amount of catalyst is $78.50 \mathrm{wt} . \%$, including gasoline fraction 17.30 wt. $\%$, and the output of the diesel fraction at a boiling point of $180-320{ }^{\circ} \mathrm{C}$ is 61.20 wt. \%. Fig. 1 compares the yield of liquid products at temperatures of 400,420 and $450{ }^{\circ} \mathrm{C}$.

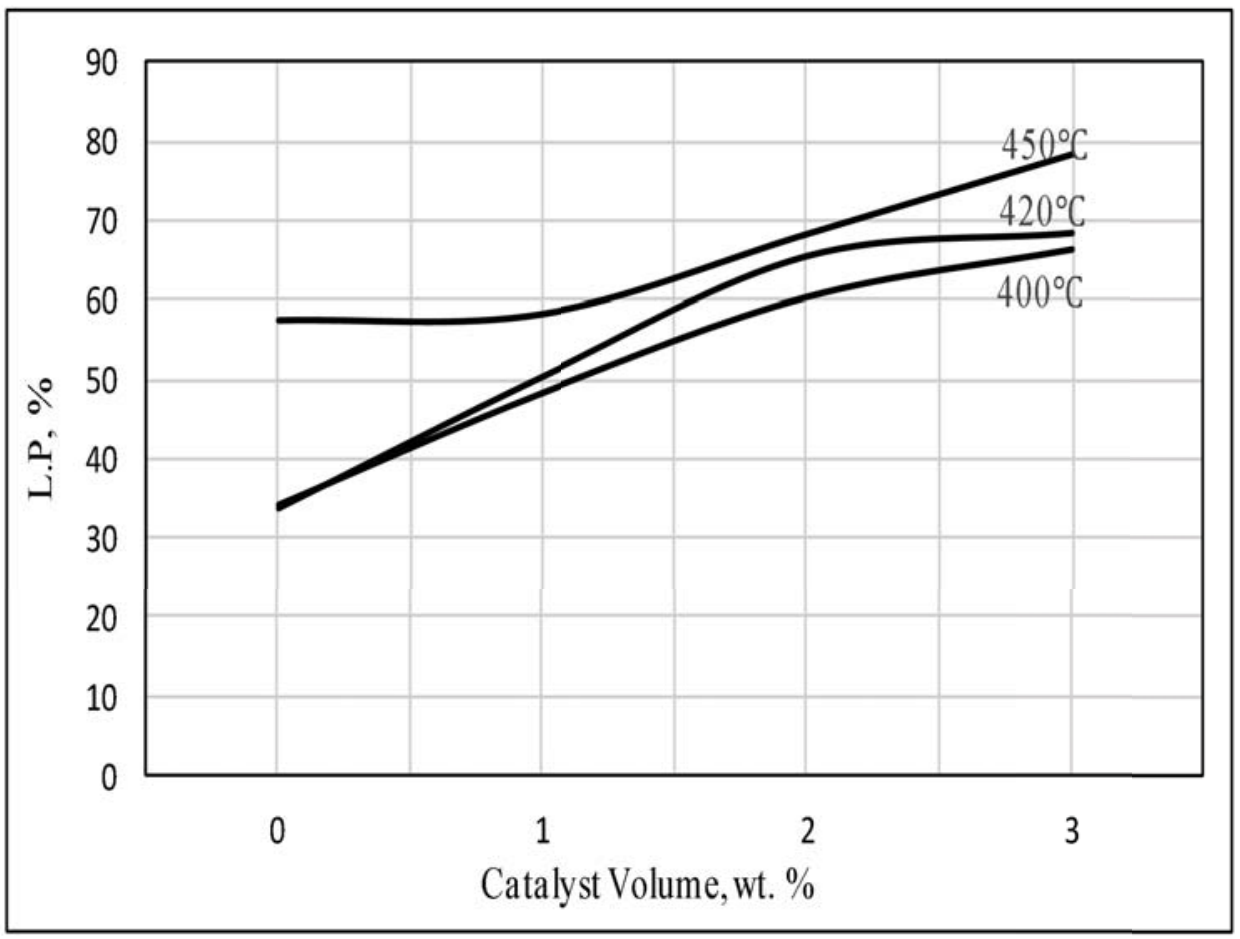

Fig. 1. Comparison of the yield of liquid products at different temperatures

As can be seen from the figures, the optimal process conditions are a temperature of $450^{\circ} \mathrm{C}$ and 3.0 wt. $\%$ of the catalyst $\mathrm{Na}_{2} \mathrm{SiO}_{3} \cdot 10 \mathrm{H}_{2} \mathrm{O}$, at which the yield of the liquid products increased from 57.6 to $78.5 \%$. The mass balance of the cracking process of cokechemical distillate products is shown in Table 3. 
Table 3. Material balance of the cracking process of coke-chemical distillate products $(\mathrm{P}=3 \mathrm{MPa}$, $\mathrm{T}=450^{\circ} \mathrm{C}$, catalyst is $\mathrm{Na}_{2} \mathrm{SiO}_{3} \cdot 10 \mathrm{H}_{2} \mathrm{O}$ )

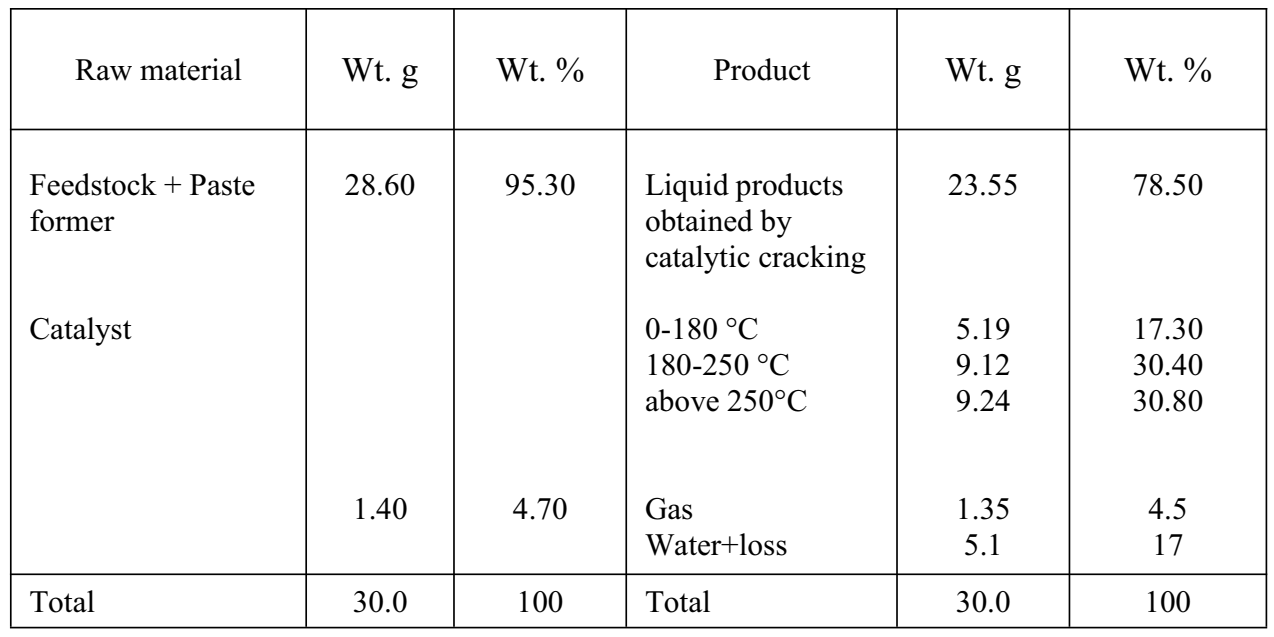

\section{Conclusions}

It was found that when heating the emulsion of the feedstock with the catalyst solution, the nanosized crystallites of the catalyst are uniformly distributed in the volume of the feedstock due to the transition from the emulsion to the phase of water vapor and cracking of the feedstock. During the cracking of coke-tar fractions boiling at $180-320{ }^{\circ} \mathrm{C}$ under conditions of $450{ }^{\circ} \mathrm{C}$ temperature and a pressure of $5 \mathrm{MPa}$, the yield of liquid product was 78.5 wt. \% including the yield of gasoline fractions $17.3 \mathrm{wt}$ \% Thus, Coke tar is identified as a potential source of raw materials for the production of motor fuels in the future.

\section{References}

1. A.A. Krichko, A.A. Ozerenko, S.B. Frosin, A.S. Maloletnev, Catal. Ind. 2, 30 (2007)

2. Zh.K. Kairbekov, A.S. Maloletnev, N.T. Smagulova, A.N. Sabitova, Solid Fuel Chem. 52320 (2018)

3. L.F. Rokhina, G.C. Shevchenko, A.D. Rokhin, V.P. Latyshev, Abstracts of Papers, Russ. Conf., Deep Processing of Solid Fossil Fuels-Russia's Strategy in the 21st Century, MGUIE, 2007, Zvenigorod, Russia (2007) 